\title{
The United Nations Convention on the Rights of Persons with Disabilities and the European Convention on Human Rights: a tale of two halves or a potentially unified vision of human rights?
}

\author{
Andrea Broderick* \\ Maastricht University, The Netherlands
}

The traditional dichotomy of rights between civil and political rights, on the one hand, and economic, social and cultural rights, on the other hand, has been increasingly eroded in scholarly and judicial discourse. The interdependence of the two sets of rights is a fundamental tenet of international human rights law. Nowhere is this interdependence more evident than in the context of the United Nations Convention on the Rights of Persons with Disabilities (CRPD or UN Convention). This article examines the indivisibility and interdependence of rights in the CRPD and, specifically, the positive obligations imposed on States Parties to the UN Convention, in particular the reasonable accommodation duty. The aim of the paper is to analyse, from a disability perspective, the approach adopted by the European Court of Human Rights (ECtHR or 'Strasbourg Court') in developing the social dimension of certain civil and political rights in the European Convention on Human Rights (ECHR), namely Articles 2 and 3 (on the right to life and the prohibition on torture, inhuman and degrading treatment, respectively), Article 8 (on the right to private and family life) and Article 14 ECHR (on non-discrimination). Ultimately, this paper examines the influence of the CRPD on the interpretation by the Strasbourg Court of the rights of persons with disabilities under the ECHR. It argues that, while the Court is building some bridges to the $C R P D$, the incremental and often fragmented approach adopted by the Court could be moulded into a more principled approach, guided by the CRPD.

Keywords: disability, equality, ECHR, CRPD, interdependence, indivisibility, positive obligations

\section{INTRODUCTION}

The traditional dichotomy of human rights between civil and political rights, on the one hand, and economic, social and cultural rights, on the other hand, has been increasingly eroded in scholarly and judicial discourse. The justifications underpinning that dichotomy have also been undermined to a large extent. In contrast to the classical negative obligation to abstain from human rights violations, it is now widely acknowledged

* My thanks go to the two anonymous reviewers for their insightful comments on the draft of this article. 
that civil and political rights may also engender positive obligations on the part of states to secure the effective enjoyment of human rights. ${ }^{1}$

The interdependence of the two sets of rights is a fundamental tenet of international human rights law. Nowhere is this interdependence more evident than in the context of the United Nations Convention on the Rights of Persons with Disabilities (CRPD or UN Convention). ${ }^{2}$ As Gerard Quinn rightly asserts, "there can be few more obvious areas than the field of disability in which to emphasise the inter-connectedness of the civil [and] political rights tradition with the more avowedly egalitarian social [and] economic rights tradition' ${ }^{3}$

Alongside an increasing interdependence of human rights, the debate on fragmentation versus systemic integration rages on in the realm of international law. Fragmentation denotes 'the rise of specialised rules and rule-systems that have no clear relationship to each other' ${ }^{4}$ Systemic integration, on the other hand, refers to the 'strong presumption [in international law] against normative conflict'. 5 That debate influences the degree to which the CRPD's vision of interdependent human rights can potentially influence other sub-systems of international law, particularly regional systems, such as the European Convention on Human Rights (ECHR). ${ }^{6}$

Within the wider context of the debate on fragmentation versus integration, this article examines the interdependence of rights in the CRPD and the positive obligations imposed on States Parties to the UN Convention, particularly the reasonable accommodation duty. The aim of this paper is to analyse the approach adopted by the European Court of Human Rights (ECtHR or 'Strasbourg Court') in developing the social dimension of certain civil and political rights in the ECHR from a disability perspective. Thereafter, this paper analyses the influence of the CRPD on the interpretation by the Strasbourg Court of the rights of persons with disabilities under the ECHR. This paper argues that, while the Court is building some bridges to the CRPD, the incremental and fragmented approach adopted by the Strasbourg Court could be moulded into a more principled approach, guided by the CRPD. Such a principled approach would entail a more careful scrutiny by the ECtHR of state action in order to ensure coherence throughout Council of Europe member states, particularly with regard to compliance with pre-existing legal obligations. It would also involve an increased role for the Court in guiding the normative framework of rights, inspired by the values embedded in the ECHR itself, and in ensuring that common standards are applied throughout Contracting States to the ECHR. It would, furthermore,

1. See Sandra Liebenberg, 'Needs, Rights and Transformation: Adjudicating Social Rights' (2006) 17 Stellenbosch Law Review 5. See also the views of Sandra Fredman, Human Rights Transformed: Positive Rights and Positive Duties (OUP, Oxford 2008); Magdalena Sepúlveda Carmona, The Nature of the Obligations Under the International Covenant on Economic, Social and Cultural Rights (Intersentia, Antwerp 2003) 127.

2. UN Convention on the Rights of Persons with Disabilities (adopted by the UN General Assembly, 24 January 2007) UN Doc A/RES/61/106.

3. Gerard Quinn, 'The International Covenant on Civil and Political Rights and Disability: A Conceptual Framework' in Theresia Degener and Yolan Koster-Dreese (eds), Human Rights and Disabled Persons: Essays and Relevant Human Rights Instruments (Martinus Nijhoff, Dordrecht 1995) 70.

4. UNGA, 'Fragmentation of International Law: Difficulties Arising from the Diversification and Expansion of International Law', Report of the Study Group of the International Law Commission, UN Doc A/CN.4/L.682, 245.

5. Ibid 25 .

6. Convention for the Protection of Human Rights and Fundamental Freedoms (adopted 4 November 1950, entered into force 3 September 1953) 213 UNTS 221. 
involve increased accountability in circumstances where states are responsible for the disadvantage experienced by an individual with a disability as a result of the state's failure to counteract socio-economic disadvantage under the applicable threshold of a particular ECHR right. Of course, all of these issues raise delicate questions surrounding the margin of appreciation granted to Contracting States under the ECHR and how that interacts, in particular, with the wide-ranging positive obligations imposed on States Parties to the CRPD.

In light of the foregoing, this article is divided into seven main sections. Following the present introductory section, Section 2 explores the debate on fragmentation versus integration in international human rights law. It also analyses the synergies that exist between the CRPD and the ECHR. Section 3 outlines the interdependence and interrelatedness of rights in the CRPD and examines the development of positive obligations under the ECHR, taking into account the implications of the margin of appreciation doctrine. Sections 4, 5 and 6 analyse the Strasbourg Court's disability case law in relation to specific ECHR articles, namely Articles 2 and 3 (on the right to life and the prohibition on torture, inhuman and degrading treatment, respectively), Article 8 (on the right to private and family life) and Article 14 ECHR (non-discrimination). ${ }^{7}$ Section 7 of this paper contains concluding remarks.

This paper is based on the classic form of legal scholarship, namely a traditional legal doctrinal approach. ${ }^{8}$ Under the doctrinal approach, the researcher examines, inter alia, the content of a legal opinion 'to evaluate whether it was effectively reasoned or to explore its implications for future cases'.

\section{FRAGMENTATION VERSUS INTEGRATION: THE CRPD AND SYNERGIES WITH THE ECHR}

The proposal to align certain aspects of the CRPD, a UN treaty, with the ECHR, a regional treaty of international law, falls within the broader theoretical frame of the debate on fragmentation versus integration in international human rights law. ${ }^{10}$ In that regard, Magdalena Forowicz distinguishes between the closed and open paradigms of the Strasbourg Court. The closed paradigm results in the maintenance of fragmentation between the ECtHR and other systems of international law, by not allowing 'the penetration of external sources into the Court's case law'. ${ }^{11}$ The open paradigm,

7. These are the articles under which there is most evidence of, and potential for, the development of protections of a socio-economic nature for persons with disabilities.

8. For a review of legal doctrinal methodology, see Martin H Redish, 'The Federal Courts, Judicial Restraint, and the Importance of Analyzing Legal Doctrine' (1985) 85 Columbia Law Review 1378.

9. Emerson H Tiller and Frank B Cross, 'What is Legal Doctrine?' (2006) 100(1) Northwestern University Law Review 517, 518.

10. See Philippa Webb, International Judicial Integration and Fragmentation (OUP, Oxford 2013); see also Martti Koskenniemi, Report of the Study Group of the International Law Commission on Fragmentation of International Law: Difficulties Arising from the Diversification and Expansion of International Law (International Law Commission, Geneva 2006). See further Bruno Simma and Dirk Pulkowski, 'Of Planets and the Universe: Self-Contained Regimes in International Law' (2006) 17(3) European Journal of International Law 483.

11. Magdalena Forowicz, The Reception of International Law in the European Court of Human Rights (OUP, Oxford 2010) 5. 
on the other hand, is one whereby the Court 'remain[s] open to external influences and cross-fertilization'. ${ }^{12}$

Isabelle Van Damme points to the fact that, while regionalised sources of international law 'may be substantively distinct from general international law', ${ }^{13}$ '[ $\left.\mathrm{t}\right]$ here is no hierarchy as such between regionalism and universalism in international law, they co-exist rather than supersede each other'. ${ }^{14}$ The legal basis for the plurality of rules that apply in interpreting treaties pertaining to sub-systems of international law and to general international law itself is the Vienna Convention on the Law of Treaties (VCLT). The primary tool of interpretation contained in Article 31 VCLT is that of textual interpretation. The context for such interpretation is outlined in Article 31(3)(c) VCLT. According to that article, the interpretation of a treaty shall take into account 'any relevant rules of international law applicable in the relations between the parties'. ${ }^{15}$ This is important in terms of the relationship between general international human rights law and the thematically specific disability regime contained in the CRPD. It is also relevant to how the ECHR, a regional regime, interacts with a thematically specific regime from international human rights law (the CRPD).

On the first point above, international law adopts a synergistic approach. The Office of the United Nations High Commissioner for Human Rights (OHCHR) maintains that all of the core international human rights treaties are mutually reinforcing and that ' $[\mathrm{r}]$ ather than being separate, free-standing treaties, the treaties complement each other, with a number of principles binding them together' ${ }^{16}$ Anthony Aust confirms that, in interpreting a treaty, one may look at 'other treaties on the same subject matter adopted either before or after the one in question which use the same or similar terms' ${ }^{17}$

The relationship between general international law and the ECHR, on the other hand, is more complex. It has been described as 'a dynamic and evolutive' relationship. ${ }^{18}$ In Bankovic and others $v$ Belgium, the Strasbourg Court said that the principles underlying the ECHR 'cannot be interpreted and applied in a vacuum' and vowed to 'determine State responsibility in conformity with the governing principles of international law'. ${ }^{19}$ Nonetheless, there are clear differences between the CRPD and ECHR in terms of the scope and applicability of the rights contained therein. The CRPD contains widespread positive duties designed to promote equality and to ensure participation of persons with disabilities in society. The positive duties in the CRPD span both civil and political as well as economic, social and cultural rights. In contrast, the fundamental aim of the ECHR is to protect civil and political rights. The ECHR places primarily

12. Ibid.

13. Isabelle Van Damme, 'What Role is there for Regional International Law in the Interpretation of the WTO Agreements?' in Lorand Bartels and Federico Ortino (eds), Regional Trade Agreements and the WTO Legal System (OUP, Oxford 2006).

14. Ibid, citing Christoph Schreuer, 'Regionalism v. Universalism' (1995) 6 European Journal of International Law 477, 498.

15. Vienna Convention on the Law of Treaties (adopted 23 May 1969, entered into force 27 January 1980) 1155 UNTS 331.

16. Office of the High Commissioner for Human Rights, The United Nations Human Rights Treaty System: An Introduction to the Core Human Rights Treaties and the Treaty Bodies, $20<\mathrm{http} / /$ www2.ohchr.org/english/bodies/docs/OHCHR-FactSheet30.pdf> accessed 26 August 2018.

17. Anthony Aust, Modern Treaty Law and Practice (2nd edn, CUP, Cambridge 2007) 200.

18. Luzius Wildhaber, 'The European Convention on Human Rights and International Law' (2007) 56 International and Comparative Law Quarterly 217, 230-231.

19. Bankovic and others v Belgium App no 52207/99 (ECtHR, 12 December 2001) (admissibility) para 57. 
negative restraints on governmental action and does not contain any specific provisions for the protection of the rights of persons with disabilities.

In spite of these differences, there are normative synergies between the two conventions, which have already been remarked upon by the Strasbourg Court. The ECtHR has stated that it views the CRPD as indicating 'a European and worldwide consensus on the need to protect people with disabilities from discriminatory treatment' ${ }^{20}$ In its recent jurisprudence ${ }^{21}$ the Court has drawn on the CRPD and its substantive provisions as an aid to interpreting the ECHR in view of its status as a 'living instrument' that 'must be interpreted in the light of present-day conditions'. ${ }^{22}$

Although the Strasbourg Court recognises the normative synergies between the two conventions, its overall approach to positive obligations is often fragmented, and this is particularly so in some of its disability case law. With a view to ascertaining whether it is realistic for the ECtHR to develop its jurisprudence in light of the interdependence of rights in the CRPD, the next section details the development of positive obligations under the ECHR and reflects on the doctrine of the margin of appreciation.

\section{THE INTERDEPENDENCE AND INTERRELATEDNESS OF HUMAN RIGHTS}

\subsection{The development of positive obligations under the ECHR}

Apart from the First Protocol to the ECHR (concerning the right to property and the right to education), the ECHR enshrines the traditional canon of civil and political rights. The Strasbourg Court has shown 'significant weariness ${ }^{23}$ in interpreting the ECHR as protecting socio-economic rights. Nonetheless, the Court has stated that it is at least willing to recognise the interdependent nature of rights in ensuring effective protection, particularly of vulnerable groups, under the ECHR. ${ }^{24}$ The Court has made clear in Airey $v$ Ireland that ' $[w]$ hilst the Convention sets forth what are essentially civil and political rights, many of them have implications of a social or economic nature' ${ }^{25}$ Thus, 'the mere fact that an interpretation of the Convention may extend into the sphere of social and economic rights should not be a decisive factor against such an interpretation'. ${ }^{26}$

20. Glor v Switzerland App no 13444/04 (ECtHR, 30 April 2009) para 53.

21. See, inter alia, DD v Lithuania App no 13469/06 (ECtHR, 14 February 2012); Mihailovs v Latvia App no 35939/10 (ECtHR, 22 January 2013); Lashin v Russia App no 33117/02 (ECtHR, 22 January 2013).

22. See eg Tyrer $v$ United Kingdom App no 5856/72 (ECtHR, 25 April 1978) para 31; see also Glor v Switzerland (n 20) para 53.

23. Liam Thornton, 'The European Convention on Human Rights: A Socio-Economic Rights Charter?' in Suzanne Egan, Liam Thornton and Judy Walsh (eds), Ireland and the European Convention on Human Rights: 60 Years and Beyond (Bloomsbury Professional, Dublin 2014) 227, <http://irserver.ucd.ie/bitstream/handle/10197/6132/Chapter_Fourteen_The_ECHR_A_SER_ Charter.docx.pdf?sequence $=1>$ accessed 26 August 2018.

24. For a comprehensive review of the development of positive obligations under the ECHR, see Alastair Mowbray, The Development of Positive Obligations Under the European Convention on Human Rights by the European Court of Human Rights (Hart Publishing, Oxford 2004).

25. Airey v Ireland App no 6289/73 (ECtHR, 9 October 1979) para 26.

26. Ibid. 
Colm O'Cinneide argues that the CRPD adopts 'a particular conceptual view of the state's role', ${ }^{27}$ whereby States Parties bear various positive obligations spanning all human rights, designed to ensure the provision of a minimum level of support to persons with disabilities, compatible with their inherent dignity. This particular viewpoint is most clearly encapsulated in the model of 'inclusive equality' contained in the Convention, ${ }^{28}$ which extends and elaborates on the content of equality, through endorsing, inter alia, 'a fair redistributive dimension to address socioeconomic disadvantages' and 'an accommodating dimension to make space for difference as a matter of human dignity'. ${ }^{29}$ It is also embodied in the 'social-contextual model of disability', ${ }^{30}$ the obligation to reasonably accommodate and the accessibility obligation under the CRPD. According to the social-contextual model espoused by the UN Convention, disability is based on the interactional relationship between people with impairments and barriers in the environment (legal, environmental and attitudinal barriers). ${ }^{31}$ The duty to accommodate imposes an obligation on States Parties to ensure that public and private entities make individualised alterations to existing structures, facilities, practices and customs that hinder the participation and inclusion of persons with disabilities in mainstream society. The accommodation duty arises upon an individualised request by a person with a disability, subject to the condition that such alterations do not constitute a disproportionate or undue burden for the duty-bearer. Notably, a failure to reasonably accommodate a person with a disability constitutes disability-based discrimination under the CRPD. By way of contrast with the accommodation duty, the accessibility obligation in Article 9 CRPD is a generalised obligation, requiring States Parties to make wide-ranging alterations to the physical environment, transportation, information and communication systems, among others, in order to ensure access on a progressive basis for all persons with disabilities. The reasonable accommodation duty, forming part of the non-discrimination norm $^{32}$ (which is a civil and political right), is immediately realisable. Combined with this immediacy, it has implications of a positive nature. The accessibility obligation is clearly socio-economic in its objectives and is progressively realisable.

While the ECHR does not share the CRPD's expansive view of the state's role, the Strasbourg Court has recognised that the purpose of the ECHR is 'to safeguard human dignity, even in the sphere of individuals among themselves'. ${ }^{33}$ Despite the ECHR's primarily negative orientation and its embodiment of traditional civil and political rights, it is clear that the rights in the ECHR apply equally to persons with disabilities as they do to all other individuals. In order to give full effect to those rights in the context of

27. Colm O'Cinneide, 'Extracting Protection for the Rights of Persons with Disabilities from Human Rights Frameworks: Established Limits and New Possibilities' in Oddný Mjöll Arnardóttir and Gerard Quinn (eds), The UN Convention on the Rights of Persons with Disabilities: European and Scandinavian Perspectives (Martinus Nijhoff, Dordrecht 2009) 164. 28. UN Committee on the Rights of Persons with Disabilities, General Comment No 6, 26 April 2018, UN Doc CRPD/C/GC/6, para 11.

29. Ibid.

30. Andrea Broderick, The Long and Winding Road to Equality and Inclusion for Persons with Disabilities: The United Nations Convention on the Rights of Persons with Disabilities (Intersentia, Antwerp 2015) 77-79.

31. For more information on the social model generally, see Tom Shakespeare (ed), Disability Rights and Wrongs (Routledge, Oxford 2006) 15-22; see also Penelope Weller (ed), New Law and Ethics in Mental Health Advance Directives: The Convention on the Rights of Persons with Disabilities and the Right to Choose (Routledge, East Sussex 2013) 27-38.

32. Arts 2 and 5 CRPD.

33. X v Netherlands, App no 8978/80 (ECtHR, 26 March 1985). 
persons with disabilities, positive measures will often be required. Lisa Waddington points to the fact that 'the obligations imposed on States Parties by the CRPD arguably create potential positive obligations for States within the context of the [ECHR]' ${ }^{34}$ The following subsection analyses how such a claim sits with the doctrine of the margin of appreciation.

\subsection{The margin of appreciation doctrine in the jurisprudence of the European Court of Human Rights}

In many respects, it is difficult to marry the ECtHR's concept of the 'margin of appreciation' with the CRPD, and, in particular, the wide-ranging positive obligations imposed on States Parties to the CRPD (with their ensuing socio-economic implications).

The margin of appreciation doctrine refers to the realm of discretion left to national authorities in fulfilling certain state obligations under the ECHR. The Court-made doctrine allows Contracting States to pursue certain actions which the Court will not interfere with, as long as those actions are deemed to fall within the acceptable margin. The boundaries of the margin of appreciation cannot be precisely defined. The application of the doctrine is context-dependent and rather unpredictable. However, there appears to be no limit, at least prima facie, to the articles to which the margin of appreciation can be applied. Notwithstanding this, the doctrine is traditionally only applied to certain ECHR articles, ${ }^{35}$ commonly Articles 8, 10 and 14 ECHR, while other rights, such as Articles 2 and 3, are considered to be absolute rights and are not subject to the doctrine.

It is noteworthy that, in determining a state's margin of appreciation, the Strasbourg Court may, where appropriate, have due regard to the 'consensus and common values emerging from the practices of European States and specialised international instruments' as well as 'the evolution of norms and principles in international law' ${ }^{36}$ The CRPD can certainly be deemed to represent an emerging consensus and a common standard on disability issues among Council of Europe member states, in particular due to the large number of ratifications that the treaty attracted in a short space of time. Moreover, as outlined above, the CRPD signals a paradigm shift in the conceptualisation of disability equality. There will, therefore, be considerable changes in the laws and policies of Council of Europe member states, which may have an impact on the interpretation by the Strasbourg Court of the rights of persons with disabilities under the ECHR. However, in invoking the CRPD to guide the interpretation of ECHR rights, the Court will be conscious of the need to guard against a greater erosion of member states' autonomy. This is particularly the case given that the ECtHR is a regional instrument and the CRPD is a UN instrument, which further reinforces the remarks made about fragmentation versus integration in Section 2 above.

34. Lisa Waddington, 'Unravelling the Knot: Article 8, Private Life, Positive Duties and Disability: Rewriting Sentges v. Netherlands' in Eva Brems (ed), Diversity and European Human Rights: Rewriting Judgments of the ECHR (CUP, Cambridge 2013) 349.

35. Ignacio de la Rasilla del Moral, 'The Increasingly Marginal Appreciation of the Margin of Appreciation Doctrine' (2005) 7(6) German Law Journal 611.

36. Opuz v Turkey, App no 33401/02 (ECtHR, 9 June 2009) para 164; see also Kiyutin v Russia, App no 2700/10 (ECtHR, 10 March 2011) fn 164; ibid para 67, where the ECtHR remarked as follows: 'The Court has consistently held that it takes into account relevant international instruments and reports in order to interpret the guarantees of the Convention and to establish whether there is a common standard in the field. It is for the Court to decide which international instruments and reports it considers relevant and how much weight to attribute to them'. 
The ECtHR is conscious of the limits of its mandate and endeavours to respect national resource allocation policies. ${ }^{37}$ The Court has stated that any positive obligations that inhere in Convention rights must not place an impossible or disproportionate burden on states. ${ }^{38}$ When dealing with obligations having a socio-economic dimension, the ECtHR has ensured that Contracting States are afforded a wide margin of appreciation. ${ }^{39}$ The Court certainly cannot incorporate all of the progressive CRPD obligations into its jurisprudence. It is constrained, inter alia, by the nature and scope of the ECHR itself. In particular, the Court cannot extend its dynamic or evolutive interpretative approach ${ }^{40}$ to derive from the CRPD a right that was not included in the ECHR at the outset. ${ }^{41}$ Nonetheless, it is arguable that the Strasbourg Court should have some regard to the substantive provisions of the CRPD when interpreting ECHR rights for persons with disabilities, within the limits of the doctrine of the margin of appreciation.

The Court has used its interpretative tools incrementally to lay the foundations for a body of jurisprudence on socio-economic rights. While there is no explicit protection granted with respect to such rights, ${ }^{42}$ Liam Thornton has claimed that the Court's interpretation of the ECHR has led to 'a more nuanced understanding and interplay'43 between socio-economic rights and civil and political rights. ${ }^{44}$

Notwithstanding this, the Strasbourg Court has adopted a fragmented approach to the development of positive obligations. Ellie Palmer argues that the Court does not clearly define the "limits of state responsibility" ${ }^{45}$ and that the "incremental reflexive approach' of the ECtHR to elaborating on positive obligations has 'failed to keep step with the emergence of a more principled approach, where positive obligations are determined in accordance with universal fundamental standards of dignity, equality and personal autonomy inherent in the Convention rights'. ${ }^{46}$

37. See Buckley v United Kingdom, App no 20348/92 (ECtHR, 25 September 1996) para 75.

38. See eg Ilascu and Others v Moldova and Russia, App no 48787/99 (ECtHR, 8 July 2004) para 332.

39. On this point, see Dimitris Xenos, 'The Human Rights of the Vulnerable' (2009) 13(4) The International Journal of Human Rights 591, 610.

40. The evolutive approach to interpretation has featured heavily in the jurisprudence of the Strasbourg Court since its early days. See eg Tyrer v United Kingdom, App no 5856/72 (ECtHR, 25 April 1978); Marckx v Belgium, App no 6833/74 (ECtHR, 13 June 1979); Dudgeon v United Kingdom, App no 7525/76 (ECtHR, 24 February 1983).

41. See the comments by Françoise Tulkens, Section President of the European Court of Human Rights, seminar on 'What are the Limits to the Evolutive Interpretation of the Convention?' (Strasbourg, January 2011) 7 <http://echr.coe.int/ Documents/Dialogue_2011_ENG.pdf> accessed 26 August 2018.

42. See Jazvinsky v Slovakia, App no 33088/96 (ECtHR, 7 September 2000), wherein the ECtHR stated that the Convention does not guarantee against violations of the rights complained of (the rights to work, social security and health).

43. Thornton (n 23) 228.

44. However, this implicit protection of socio-economic rights under the ECHR is disputed. See, for instance, Merrills, who cautions against the ECtHR reinterpreting the Convention by reading socio-economic protection into Convention provisions: John Graham Merrills, The Development of International Law by the European Court of Human Rights (2nd edn, Manchester University Press, Manchester 1993) 102.

45. Ellie Palmer, 'Protecting Socio-Economic Rights Through the European Convention on Human Rights: Trends and Developments in the European Court of Human Rights' (2009) 2(4) Erasmus Law Review 397, 402.

46. Ibid 425. 
While the Court's disability case law suggests that the traditional division between civil and political rights and socio-economic rights may be waning, the Court seems to run "hot and cold" ${ }^{47}$ in its case law, and the emerging body of jurisprudence in the field of disability does not always embody a principled approach. It is submitted that the CRPD could aid the Strasbourg Court in moulding this more principled approach.

In its preamble, the CRPD reaffirms 'the universality, indivisibility, interdependence and interrelatedness of all human rights and fundamental freedoms' ${ }^{48}$ The CRPD also maintains the traditional dichotomy between civil and political rights, and rights of a socioeconomic nature, in Article 4(2). Notwithstanding this, the dividing lines between the two sets of rights are blurred throughout the substantive provisions of the UN Convention. Michael Ashley Stein asserts that the CRPD encompasses a 'disability human rights paradigm ${ }^{49}$ that challenges the traditional but unsustainable gap between immediately realisable civil and political rights and progressive socio-economic rights. Many of the substantive articles in the UN Convention encompass 'hybrid' rights. Several CRPD rights that fall under the traditional category of socio-economic rights (such as the rights to education and employment) contain reasonable accommodation requirements. In addition, many civil and political rights in the CRPD require positive measures and expenditure on the part of states. In that regard, the right to liberty and security of the person, the right to freedom of expression and the right to participate in political and public life all place obligations on States Parties to ensure the provision of reasonable accommodation ${ }^{50}$ and to adopt accessibility measures. ${ }^{51}$ Thus, many CRPD rights which have traditionally been considered 'negative' or budget-neutral rights, in fact require positive measures to be adopted in the context of persons with disabilities in order to ensure the realisation of those rights. ${ }^{52}$

The duty to accommodate is of pivotal importance, since it is located within the nondiscrimination norm in that an unjustified failure to provide reasonable accommodation is a form of discrimination. This makes the disability case law of the ECtHR a particularly interesting field to study in the context of the interdependence of human rights, as the enjoyment of ECHR rights by persons with disabilities on an equal basis with others will, in many cases, give rise to positive obligations in the form of a reasonable accommodation. As noted above, the reasonable accommodation duty is subject to a disproportionate burden defence. Thus, unlike the wide-ranging and potentially unlimited accessibility obligations contained in the CRPD, the explicit incorporation of reasonable accommodation duties under the ECHR should not encroach too far on Contracting States' national autonomy. It is submitted that the Strasbourg Court should develop a clearer duty to reasonably accommodate persons with disabilities under the ECHR, since the failure to incorporate reasonable accommodation duties into the Court's

47. Lisa Waddington, 'Handicap, Discrimination by Association, Indirect onderscheid, Toegankelijkheid, VN-gehandicaptenverdrag' (2016) 130 European Human Rights Cases, para 18. 48. CRPD, preamble, para c.

49. See generally Michael Ashley Stein, 'Disability Human Rights' (2007) 95 California Law Review 75.

50. CRPD, art 14(2) on the right to liberty and security of the person.

51. CRPD, art 21(a)-(e) on freedom of expression. See also art 29, which requires States Parties to ensure that 'voting procedures, facilities and materials are appropriate, accessible and easy to understand and use'.

52. See generally Ida Elizabeth Koch, 'From Invisibility to Indivisibility: The International Convention on the Rights of Persons with Disabilities' in Oddný Mjöll Arnardóttir and Gerard Quinn (n 27) 95. 
jurisprudence results in clear instances of discrimination. With regard to more far-reaching accessibility obligations, the Strasbourg Court clearly cannot justify including these within ECHR rights. There may, however, be instances whereby the failure of the Court to at least monitor states' non-compliance with preexisting accessibility duties at the national level will give rise to disadvantage for a person with a disability under the applicable threshold of ECHR rights.

In this light, the next three sections explore the development of disability rights within the Strasbourg Court's jurisprudence. The case law chosen is intended to demonstrate both chronological developments as well as the current state of affairs post-CRPD. An analysis of the emerging trends in the Court's case law will enable a determination of the influence of the CRPD in relation to the protection of the rights of persons with disabilities in detention settings, with regard to the enjoyment of private life, as well as in the exercise of the right to non-discrimination. Ultimately, this paper argues that a more integrated approach on the part of the ECtHR would result in a more consistent protection of disability rights throughout the Council of Europe and in States Parties to the CRPD.

\section{EQUAL ENJOYMENT OF THE RIGHT TO LIFE AND FREEDOM FROM INHUMAN AND DEGRADING TREATMENT}

The Strasbourg Court's recent case law on the conditions of detention for persons with disabilities suggests that the right to life under Article 2 ECHR may impose certain limited - duties of a socio-economic nature on states, ${ }^{53}$ especially where states already have in place existing domestic duties to that effect. ${ }^{54}$ With regard to Article 3 ECHR (which contains the prohibition on torture), the Court has held that it may engender potential socio-economic obligations for Contracting States. However, the threshold that applicants have to reach to demonstrate a breach of Article 3 is high - in essence, applicants must demonstrate that the prevailing conditions are so poor as to constitute inhuman and degrading treatment beyond that which inevitably goes with imprisonment for the commission of a crime. ${ }^{55}$

The following subsections briefly examine pre-CRPD case law on Articles 2 and 3, before analysing the ECtHR's post-CRPD case law on the same articles in order to determine the extent to which the CRPD has already influenced the Court's approach to positive duties and whether there is further room for the CRPD to influence the Court's disability case law concerning detention settings.

53. See eg Center for Legal Resources on Behalf of Valentin Câmpeanu v Romania App no 47848/08 (ECtHR, 17 July 2014), which concerned a young man who was HIV-positive and suffering from a severe psychosocial disability. In that case, the Court held that there had been, inter alia, a violation of art 2 of the Convention. Valentin Câmpeanu had been placed in medical facilities that were not equipped to provide adequate care for his condition (due to lack of personnel, insufficient food and lack of heating). He had been transferred from one unit to another without proper diagnosis, and the authorities had failed to ensure his appropriate treatment with antiretroviral medication. 54. See eg Nencheva and Others v Bulgaria App no 48609/06 (ECtHR, 18 June 2013), wherein the failure to provide adequate food and nourishment, heating and medical care to children with profound disabilities under the state's care was held to have violated art 2 ECHR. Notably, the Bulgarian authorities had an obligation under domestic law to care for the children in question (see paras 63-67 and 118 of the judgment).

55. See, among others, Kudla v Poland App no 30210/96 (ECtHR, 26 October 2000) para 94. 


\subsection{Pre-CRPD case law on Articles 2 and 3 ECHR}

Before the entry into force of the CRPD, the ECtHR did not hesitate in finding a violation of Article 3 ECHR in circumstances where the special needs of a detainee with a disability were not taken into account by the authorities in institutional settings. In Price v United Kingdom, ${ }^{56}$ the Strasbourg Court ruled that the state in question had inflicted degrading treatment on the applicant - a woman with a disability in state custody - contrary to Article 3 ECHR, by virtue of the fact that it had failed to accommodate her particular needs arising from her impairment. The ECtHR ruled that the conditions of detention imposed on the applicant, including inaccessible toilets and bed, amounted to degrading treatment under Article 3, notwithstanding the lack of any evidence of an intention to humiliate Ms Price. Olivier de Schutter observes that '[i]t was the lack of any consideration of Ms. Price's special needs, therefore, which led to the Court's finding that degrading treatment had taken place'. ${ }^{57}$ While the Strasbourg Court 'did not use the language of reasonable accommodations and it did not take the opportunity to frame the rights of the applicant in terms of non-discrimination or equality', one could argue that 'this could not have been expected of the Court as far back as 2001 when the concept of reasonable accommodation was relatively new and unknown in international and European law at that point'. ${ }^{58}$ The duty established in the Price ruling is, therefore, a de facto and limited one, confined to institutional settings and also to the substantive ECHR right at issue. ${ }^{59}$

\subsection{Post-CRPD case law on Articles 2 and 3 ECHR}

Since the coming into force of the CRPD, the ECtHR has demonstrated a similar trend as its pre-CRPD case law in locating de facto reasonable accommodation duties within Articles 2 and 3 ECHR. ${ }^{60}$ This trend has arisen due to the fact that the specific circumstances of detainees with disabilities were not taken into account by the relevant state authorities. In some cases, the Strasbourg Court does not refer to the CRPD at all or to the concept of 'reasonable accommodation' contained in the UN Convention ${ }^{61}$ but places emphasis on the 'circumstances of the disabled detainee', to rule that the level

56. See Price v United Kingdom App no 33394/96 (ECtHR, 10 July 2001) para 30.

57. Olivier de Schutter, 'Reasonable Accommodation and Positive Obligations in the European Convention on Human Rights' in Anna Lawson and Caroline Gooding (eds), Disability Rights in Europe: From Theory to Practice (Hart Publishing, Oxford 2005) 55.

58. Broderick (n 30) 337.

59. Ibid.

60. Ibid.

61. See eg the cases of Khudobin v Russia App no 59696/00 (ECtHR, 26 October 2006); Rupa v Romania App no 58478/00 (ECtHR, 16 December 2008); Kupczak v Poland App no 2627/09 (ECtHR, 25 January 2009); Xiros v Greece App no 1033/07 (ECtHR, 9 September 2010); Grori v Albania App no 25336/04 (ECtHR, 7 July 2009); Raffrey Taddei v France App no 36435/07 (ECtHR, 21 December 2010); Logvinenko v Ukraine App no 13448/07 (ECtHR, 14 October 2010); Vasyukov v Russia App no 2974/05 (ECtHR, 5 April 2011); Vladimir Vasilyev $v$ Russia App no 28370/05 (ECtHR, 10 January 2012); Artyunyan v Russia App no 48977/09 (ECtHR, 10 January 2012); Grzywaczewski v Poland App no 18364/06 (ECtHR, 31 May 2012); Semikhvostov v Russia App no 2689/12 (ECtHR, 6 February 2014); 区bele v Latvia App nos 60429/12 and 72760/12 (ECtHR, 5 October 2017). 
of suffering breached the threshold. ${ }^{62}$ In other cases, the Court appears to be showing increased cognisance of the relevant CRPD provisions in reading measures of a socio-economic nature into the rights of persons with disabilities in detention settings. One is led to question whether the Strasbourg Court is more inclined to recognise the duty to accommodate as an inherent part of the exercise of equal rights for persons with disabilities in institutional and other settings because of the norms contained in the CRPD.

In Jasinskis $v$ Latvia, ${ }^{63}$ the Court held that there was a violation of Article 2 ECHR in circumstances where the domestic authorities had failed to provide medical assistance to, and to communicate properly with, the applicant - a seriously injured deaf man who was unable to speak. While the Court did not use the term 'reasonable accommodation', it did cite Article 14(2) CRPD, which requires States Parties to provide reasonable accommodations where persons are deprived of their liberty. In the subsequent case of Z.H. v Hungary ${ }^{64}$ - in the context of an alleged violation of Article 3 ECHR, taken in conjunction with Article 5(2) ECHR - the Court cited the definition of reasonable accommodation in Article 2 CRPD. The Court also referred to Article 13 CRPD, which requires States Parties to provide "procedural and ageappropriate accommodations' to persons with disabilities in accessing justice. Moreover, the Court employed the "vulnerable groups' ${ }^{65}$ approach and stated that 'any interference with the rights of persons belonging to particularly vulnerable groups such as those with mental disorders - is required to be subject to strict scrutiny, and only very weighty reasons could justify any restriction'. ${ }^{66}$

The 'vulnerable groups approach' or the 'vulnerability approach' provides a potential means by which to tackle structural inequalities issues. Lourdes Peroni and Alexandra Timmer are of the opinion that the Court's use of the notion of group vulnerability 'represents a crucial step towards an enhanced anti-discrimination case law and a more robust idea of equality'. ${ }^{67}$ In Z.H., the Court used the vulnerability approach to read into Article 3 ECHR an obligation to take 'reasonable steps' to prevent situations likely to result in inhuman and degrading treatment. ${ }^{68}$ The notion of 'reasonable steps' was likened to that of 'reasonable accommodation' in Articles 2, 13 and 14 of the CRPD ${ }^{69}$ and, therefore, would appear to signify that the Court is building a bridge towards CRPD-type reasonable accommodation duties.

62. For further discussion on this point, see Anna Lawson, 'Disability Equality, Reasonable Accommodation and the Avoidance of Ill-Treatment in Places of Detention: The Role of Supranational Monitoring and Inspection Bodies' (2012) 16(6) The International Journal of Human Rights 845, 851.

63. Jasinskis v Latvia App no 45744/08 (ECtHR, 21 December 2010).

64. Z.H. v Hungary App no 28973/11 (ECtHR, 8 November 2012).

65. For a detailed examination of group vulnerability in the ECtHR's case law, see the following articles: Alexandra Timmer, 'Toward an Anti-Stereotyping Approach for the European Court of Human Rights' (2011) 11(4) Human Rights Law Review 707; Lourdes Peroni and Alexandra Timmer, 'Vulnerable Groups: The Promise of an Emergent Concept in European Human Rights Convention Law' (2013) 11 International Journal of Constitutional Law 1056. In addition, see Alexandra Timmer, 'A Quiet Revolution: Vulnerability in the European Court of Human Rights', in Martha Fineman and Alison Grear (eds), Vulnerability: Reflections on a New Ethical Foundation for Law and Politics (Routledge, New York 2013) 147-170.

66. Z.H. v Hungary (n 64) para 29.

67. Peroni and Timmer (n 65) 1074.

68. Z.H. v Hungary (n 64) para 31.

69. Ibid para 43. 
In the case of D.G. $v$ Poland ${ }^{70}$ the ECtHR demonstrated its inconsistent use of the CRPD by failing to mention it in the course of its judgment, even though it was clearly relevant to the facts of the case. In the subsequent judgment of Grimailovs $v$ Latvia, ${ }^{71}$ the ECtHR again referred to the CRPD in the context of relevant international law, citing the definition of reasonable accommodation in Article 2 CRPD and the obligation contained in Article 14(2) CRPD to provide reasonable accommodations in detention settings. The Court also directed attention to the inaccessibility of the relevant facilities and found that the applicant's inability to have access to various prison facilities amounted to degrading treatment contrary to Article 3 ECHR. However, as Waddington points out, 'the Court made no direct or implied reference to the aforementioned "reasonable accommodation" obligation as a means of alleviating the applicant's suffering' in the context of this inaccessibility. ${ }^{72}$

While the ECtHR appears to be (more) willing to read de facto reasonable accommodation duties into Articles 2 and 3 ECHR and to take increased cognisance of the CRPD in its case law, the existing body of jurisprudence shows that the Court is unwilling to declare principles of general application of a socio-economic nature as falling within the protection provided by Article 3 ECHR. In particular, the Court shies away from pronouncing obligations to provide social support in the form of medical treatment or assistive devices, given the possible resource implications this may have for states. In the post-CRPD case of Zarzycki v Poland, ${ }^{73}$ the applicant - a man with both forearms amputated - complained that his detention without adequate medical assistance for his special needs and without refunding him the cost of more advanced bio-mechanical prosthetic arms was in violation of Article 3 ECHR. In denying the applicant relief, the Strasbourg Court noted the proactive attitude of the prison administration vis-à-vis the applicant. The Court also ruled that the domestic authority could not be said to have failed to discharge its obligations under Article 3 ECHR by not paying the full costs of the more advanced prosthetic device. The Court took into account the fact that a basic-type mechanical prosthesis had been provided to the applicant free of charge and that a refund of a small part of the cost of bio-mechanical prostheses had also been made available to the applicant. Thus, in spite of the applicant's particular vulnerability to the hardships of detention, the Court held, without any further investigation, that the threshold of severity required to constitute degrading treatment under Article 3 ECHR had not been reached.

\subsection{Potential future influence of the CRPD on the rights of persons with disabilities in detention}

Article 15(1) CRPD contains a similar obligation to that contained in Article 3 ECHR. Article 15(2) CRPD requires States Parties to 'take all effective legislative, administrative, judicial or other measures to prevent persons with disabilities, on an equal basis with others, from being subjected to torture or cruel, inhuman or degrading treatment or punishment'. ${ }^{74}$ Furthermore, Article 14(2) CRPD requires States Parties to

70. D.G. v Poland App no 45705/07 (ECtHR, 12 February 2013).

71. Grimailovs v Latvia App no 6087/03 (ECtHR, 25 June 2013).

72. Lisa Waddington, 'Europees Hof voor de Rechten van de Mens, Grimailovs tegen Letland', No 6087/03 (25 June 2013) European Human Rights Cases 2286, 2304.

73. Zarzycki v Poland App no 15351/03 (ECtHR, 12 March 2013).

74. Emphasis added. 
provide reasonable accommodations where persons with disabilities have been deprived of their liberty. The CRPD clearly perceives positive obligations, specifically those in the form of reasonable accommodations, 'as an essential element of disability equality ${ }^{75}$ in the context of deprivation of liberty and beyond.

The ECtHR has ruled that persons with disabilities constitute a particularly vulnerable and marginalised group in society and has linked this finding to the CRPD. ${ }^{76}$ The concept of 'vulnerability' does not sit well with the CRPD, which endorses an empowering approach to disability and endeavours to overcome the stigmatisation of persons with disabilities. Nonetheless, Lourdes Peroni and Alexandra Timmer highlight the fact that group vulnerability acts as a 'magnifying glass', ${ }^{77}$ in the sense that the alleged violation of rights 'looks bigger through the vulnerability lens'. ${ }^{78}$ This is evident in the $Z$.H. case above, where the special needs of the applicant featured strongly in the Court's pronouncement of an obligation to take 'reasonable steps' to accommodate the needs of the applicant.

While the ECtHR has already drawn on the CRPD, in many cases, to inform its interpretation of ECHR rights for persons with disabilities in detention settings, the Court 'appears reluctant to specify the exact duty to accommodate which States bear in the disability context' ${ }^{79}$ In addition, the ECtHR locates the disadvantage encountered by individuals with disabilities within the substantive provisions of the ECHR and does not seem to have grasped the discriminatory nature of the failure to provide reasonable accommodations in institutional settings. ${ }^{80}$ While the ECtHR's approach is not always consistent, there is a clear recognition by the Court that some form of reasonable accommodation is necessary to ensure equal enjoyment of rights by persons with disabilities in detention. As demonstrated above, the Court has even likened the state obligations which it has read into ECHR rights for prisoners with disabilities to the CRPD's duty to accommodate. The development of the concept of 'reasonable accommodation', particularly by the CRPD Committee, may influence the Court to specify more clearly the scope of states' duties towards prisoners with disabilities. Furthermore, the use of the vulnerability approach, in conjunction with the Court's invocation of the CRPD, may result in an increased awareness of the inequalities experienced by people with disabilities in detention settings. This may convince the Court of the merits of increased positive obligations in that context, particularly in light of the specific situation of detainees - with disabilities - as individuals who are in a situation of complete dependence on the state.

It is questionable, however, whether the ECtHR will expand the reach of Articles 2 and 3 ECHR any further than a bare reasonable accommodation duty in circumstances where delicate resource implications are at stake. As seen above, the Court appears

\section{Broderick (n 30) 336.}

76. See eg Alajos Kiss v Hungary App no 38832/06 (ECtHR, 20 May 2010). That case related to a blanket ban on the right to vote of an individual with a psychosocial disability, where the ECtHR grounded its findings partly on the approach adopted in instruments of international law, including the CRPD. In that case, the Court concluded unanimously that a blanket restriction on the franchise of persons with disabilities, or a category of persons with certain forms of disabilities, contravened art 3, Protocol 1 ECHR (on the right to free elections) and was, therefore, not within a state's margin of appreciation.

77. Peroni and Timmer (n 65) 1079.

78. Ibid.

79. Broderick (n 30) 346.

80. Ibid 343. 
reluctant to read anything but a limited form of socio-economic benefit into Articles 2 and 3 ECHR and is reluctant to reassess the applicable thresholds under the ECHR where some assistance has already been provided by the state in question. While it is certainly understandable that the Strasbourg Court does not want to interfere with the domestic autonomy of Contracting States, it is less clear why the Court does not see fit to examine the cases as non-discrimination cases and confines itself to an examination of the substantive rights at issue instead. Presently, the reason for the Court's insistence on de facto reasonable accommodation duties in prison or institutional settings appears to relate to the grave nature of the potential breaches of rights involved and the applicants' particularly vulnerable situation, leaving aside the issue of disability. In light of the clear relevance of the non-discrimination norm to these cases, it is submitted that the Court could adopt a more consistent approach to the CRPD as an interpretative guide for ECHR rights.

\section{EQUAL ACCESS TO PRIVATE LIFE FOR PERSONS WITH DISABILITIES}

In certain areas of its jurisprudence, the Strasbourg Court has interpreted the substantive elements of Article 8 ECHR as well as the notion of 'respect' inherent in Article 8(1) quite expansively. ${ }^{81}$ This has supported the development of a wide range of positive and negative obligations under the ECHR. ${ }^{82}$ In the disability context, three particular aspects covered by the concept of 'private life' are relevant, ${ }^{83}$ namely physical and psychological integrity, the right to autonomy or self-determination and the right to establish relationships with other human beings.

The Court has stated that Article 8 may, in exceptional circumstances, require positive social provision for individuals who are particularly vulnerable. In that connection, the Court's analysis boils down to the examination of two different factors, namely the existence of a 'direct and immediate link between the measures sought by an applicant and the latter's private ... life ${ }^{84}$ and the striking of a fair balance between individual interests and the general interests of society at large. This represents a two-step approach, or bifurcation, between the scope of application of the relevant right and the review of a state's justification for the alleged breach of rights. However, the ECtHR has not always been transparent in the approach that it takes to assessing disability claims and determining state liability for breach of Article 8 . The Court has generally granted states a very wide margin of appreciation. ${ }^{85}$ In particular, it is the quantitative element of positive obligations, in terms of financial cost - and reflected

81. On this point, see generally Keir Starmer, 'Positive Obligations Under the Convention' in Jeffrey Jowell and Jonathan Cooper (eds), Understanding Human Rights Principles (Hart Publishing, Oxford 2001) 156.

82. See among others Van Kück v Germany App no 35968/97 (ECtHR, 12 June 2003); L v Lithuania App no 27527/03 (ECtHR, 11 September 2007).

83. See Waddington (n 34), citing Paul Bowen's analysis of the Court's case law. Paul Bowen 'Article 8 and "Private Life": The Protean Right' (ALBA Seminar, Doughty Street Chambers 2010) at 6-8.

84. Botta v Italy App no 21439/93 (ECtHR, 24 February 1998); Zehnalová and Zehnal $v$ the Czech Republic App no 38621/97 (ECtHR, 14 July 2002); Sentges $v$ the Netherlands App no 27677/02 (ECtHR, 8 July 2003).

85. See the arguments by Colm O'Cinneide, 'Extracting Protection for the Rights of Persons with Disabilities from Human Rights Frameworks: Established Limits and New Possibilities' in Oddný Mjöll Arnardóttir and Gerard Quinn (n 27) 184. 
in the floodgates theory ${ }^{86}$ - that has restricted the Court's intervention and, thus, the imposition of positive obligations on states. ${ }^{87}$

There is little relevant post-CRPD case law on positive obligations under Article 8 ECHR in the disability context. ${ }^{88}$ Thus, the following subsection examines pre-CRPD case law under Article 8, in order to set out the Court's approach to disability claims to date.

\subsection{Pre-CRPD case law on positive obligations under Article 8 ECHR}

The ECtHR's pre-CRPD case law on positive obligations under Article 8 has generally been criticised for its fragmented approach. ${ }^{89}$ In two cases relating to general accessibility measures, Botta v Italy ${ }^{90}$ and Zehnalová and Zehnal v the Czech Republic, ${ }^{91}$ the applicants had claimed, respectively, that the right to private life inherent in Article 8 had been infringed when the relevant public authorities had failed to ensure that a private beach was physically accessible and that public buildings were accessible to people with impaired mobility. The claim in Botta was rejected on the basis that the right asserted concerned 'interpersonal relations of such a broad and indeterminate scope, 92 that no positive obligations could be imposed on the state. In Zehnalová, the Court emphasised that positive obligations will only be found in exceptional circumstances where a special link is deemed to exist between the measure sought and the exercise of Article 8 rights. ${ }^{93}$ The Court doubted the existence of such a link in Zehnalová on account of a lack of convincing evidence pointing to the daily use of the large number of buildings mentioned by the applicants. ${ }^{94}$

The outcome of these cases can be seen as predictable, in the sense that the Court is not willing to impose on states progressively realisable obligations entailing wideranging restructuring of the environment. Nonetheless, it is the Court's failure to follow the 'bifurcation between the definition of scope and the review of justification' 95 (where positive obligations are at stake under Article 8) that has attracted most criticism.

86. The Court has expressly anticipated this aspect of claims in the case of Sentges $v$ Netherlands and in Pentiacova and 48 Others v Moldova App no 14462/03 (ECtHR, 4 January 2005).

87. See the arguments by Xenos (n 39) 604.

88. There are some exceptions. See Bayrakci v Turkey, App No 2643/09 (ECtHR, 28 February 2013), a case that was declared inadmissible. See also Kacper Nowakowski v Poland, App No 32407/13 (ECtHR, 10 January 2017).

89. See eg Oliver De Schutter (n 57); see also Maria Ventegodt Liisberg, Disability and Employment: A Contemporary Disability Human Rights Approach Applied to Danish, Swedish and EU Law and Policy (Intersentia, Antwerp 2011).

90. Botta $v$ Italy (n 84).

91. Zehnalova and Zehnal $v$ the Czech Republic (n 84).

92. Botta $v$ Italy (n 84) para 35.

93. Translation of Zehnalová and Zehnal v the Czech Republic, para $12<\mathrm{http}: / /$ hudoc.echr.coe. int/app/conversion/pdf/?library=ECHR\&id=001-23341\&filename=001-23341.pdf $>$ accessed 2 April 2018.

94. Ibid.

95. Eva Brems and Janneke Gerards (eds), Shaping Rights in the ECHR: The Role of the European Court of Human Rights in Determining the Scope of Human Rights (CUP, Cambridge 2014) 176. See also the arguments put forward in Janneke Gerards and Hanneke Senden, 'The Structure of Fundamental Rights and the European Court of Human Rights' (2009) 7(4) International Journal of Constitutional Law 619. 
Other cases brought before the Court have related to more individualised and specific reasonable accommodation-type measures. Sentges $v$ the Netherlands ${ }^{96}$ is one such example. That case concerned a man suffering from Duchenne Muscular Dystrophy, which rendered him completely dependent on others. The applicant asserted that the state had failed to discharge its positive obligations inherent in Article 8 ECHR by refusing to provide him with a robotic arm, costing in the region of $€ 36,000$. By that token, the applicant claimed that the domestic authorities had breached his right to respect for his private life and, more specifically, his right to establish and develop relationships with other human beings as well as his right to self-determination. ${ }^{97}$ Notwithstanding this, the Court granted the state a wide margin of appreciation. It did so on the basis that some support had already been provided to the applicant ${ }^{98}$ and that providing further support would impose a stringent financial burden on the state. The Court also displayed further evidence of its inconsistent approach to positive obligations in Sentges ${ }^{99}$ by virtue of the fact that it did not consider whether a direct and immediate link had been established by the applicant between the measures sought and the right in question and, therefore, whether Article 8 was applicable. Instead, the Court went directly to the balancing stage of its analysis.

These cases demonstrate the unwillingness of the Court to intervene when it comes to the socio-economic dimension of the guarantees inherent in Article 8. Even where the claim concerns an individualised reasonable accommodation-type claim, which is more limited in nature than a general claim that the environment be made accessible for all individuals with disabilities, the Court shies away from intervening. While it is understandable that the margin of appreciation is left to Contracting States on resource allocation issues, the main problem, as de Schutter points out, lies in identifying 'the precise scope of the positive obligations which may be imposed on the State'. ${ }^{100}$ In that light, it is apt to consider whether the CRPD could help in clarifying the scope of 'permissible' positive obligations that could potentially be imposed under Article 8 ECHR.

\subsection{The potential influence of the CRPD on the interpretation of positive obligations under Article 8 ECHR}

This section proposes the introduction of 'reasonable accommodation'-style reasoning under Article 8 and justifies such an introduction on several fronts.

The wide-ranging rights in the CRPD are potentially relevant to the interpretation of Article 8 ECHR in light of the large number of Council of Europe States that have ratified the CRPD and are currently implementing it at the national level. The underlying principles and values of the CRPD centre on the development of personhood and promoting 'full and effective participation in society on an equal basis with others'. ${ }^{101}$ The core obligations inherent in many CRPD rights, in particular Article 19 - requiring States Parties to take effective and appropriate measures to facilitate full inclusion and participation in the community, including through the provision of individualised

96. Sentges $v$ the Netherlands (n 84).

97. Ibid para 5.

98. The Court relied partly on the finding that the applicant had already received some assistance (ie an electric wheelchair with an adapted joystick), having met the applicable disability and income-based criteria.

99. On that point, see Waddington (n 34) 341.

100. De Schutter (n 57) 45.

101. CRPD, art 1. 
support - have potential relevance to the interpretation of Article 8 ECHR. Moreover, Article 17 CRPD provides that 'every person with disabilities has a right to respect for his or her physical and mental integrity on an equal basis with others', which necessarily implies an entitlement to reasonable accommodations to facilitate this.

Waddington claims that the CRPD may lead the ECtHR to find 'that States have a narrower margin of appreciation with regard to article 8 , to the extent that the right protected by article 8 is also protected by the CRPD'. ${ }^{102}$ The scope of positive obligations under the ECHR, and particularly under Article 8, cannot be unlimited. This has been clearly demonstrated by the Strasbourg Court in many cases. ${ }^{103}$ Thus, more widespread claims for general accessibility are unlikely to be accepted by the Court.

On the basis of the ECtHR's case law, outlined above, Mr Justice Munby concludes that the concept of physical and psychological integrity inherent in Article 8 ECHR includes the right of persons with disabilities to participate in the life of the community and to have 'access to essential economic and social activities and to an appropriate range of recreational and cultural activities' ${ }^{104}$ In order to achieve these ends, persons with disabilities require, at the very least, some form of reasonable accommodation. The question that remains to be resolved is whether the CRPD's reasonable accommodation duty can help the Court in identifying appropriate limitations for the introduction of certain positive obligations under Article 8 ECHR.

It is submitted that, in order to advance the Court's disability case law, a clear structure should be adopted by the Strasbourg Court in its assessment of claims related to positive obligations, instead of the Court's approach in the past, which merges considerations of the scope of ECHR rights and the review of state justifications. In Zehnalová, the Court noted that positive obligations attaching to disruptions to personal life which affect the development of one's personality apply only in exceptional circumstances. Accordingly, as Dimitris Xenos has pointed out, 'the actionable degree of negative impact under article 8 is assessed in negative terms, namely to identify the critical level at which an individual cannot develop [his/her] personality'. ${ }^{105}$ With a view to promoting a harmonised set of common values among States Parties to both the ECHR and the CRPD, it is submitted that this actionable threshold should be aligned with the values and objectives underlying the reasonable accommodation duty.

The reasonable accommodation duty requires that measures must be 'necessary and appropriate'. ${ }^{106}$ This means ensuring that the person in question can participate in the relevant activity. ${ }^{107}$ The ECtHR will have to make its own assessment, on a case-bycase basis, as to whether the measure sought, or indeed the part-measures or measures already granted to the individual with a disability, are effective in ensuring participation by that individual under Article 8 thresholds. Once the applicable threshold has been assessed under Article 8, the Court should proceed directly to the second level of review. According to the CRPD's reasonable accommodation duty, this would involve the Court assessing the justifications put forward by states in deciding whether

102. Waddington (n 34) 349.

103. See La Parola v Italy App no 39712/98 (ECtHR, 30 November 2000).

104. Waddington (n 34), citing Mr Justice Munby, 'Human Rights: Transforming Services? Human Rights and Social Welfare Law: The Impact of Article 8', Social Care Institute for Excellence <www.scie.org.uk/news/events/previousevents/humanrights06/mrjusticemunby. pdf $>$ accessed 26 August 2018.

105. Xenos (n 39) 602.

106. CRPD, art 2.

107. Broderick (n 30) 175. 
granting a particular measure to an applicant with a disability constitutes a disproportionate burden under the applicable threshold. Much like the CRPD's reasonable accommodation duty, which assumes protection for the individual - subject to proof that the burden is indeed disproportionate - a request for positive provision should not be dismissed automatically by the Court, nor should it be merged with the justification stage (as it has been in previous decisions). Instead, there should be two clear steps in the Court's jurisprudence.

The Strasbourg Court has already stated that any positive obligation imposed on states must not be such as to impose an impossible or disproportionate burden on the authorities. ${ }^{108}$ While the concept of 'disproportionate burden' is fraught with difficulty, some level of guidance can be drawn by the ECtHR from the CRPD itself and from the evolving interpretation of the concept by the CRPD Committee.

In theory, the Strasbourg Court is not totally opposed to positive obligation claims by applicants with disabilities. However, it is (understandably) concerned with limiting the number of claims. By definition, reasonable accommodations are not overly resourceintensive, owing to the fact that granting a reasonable accommodation is always subject to the disproportionate burden defence. With regard to more generalised accessibility obligations, the situation is much trickier and the scope of the ECHR does not support a liberal reading of such measures within its ambit. Nonetheless, there are certain ways in which the ECtHR can adopt a more coherent approach to disability rights in that regard.

Firstly, since many Council of Europe member states have already laid down (or are in the process of laying down) far-reaching accessibility obligations in line with the CRPD, the ECtHR should be more stringent in its assessment of state action, in order to ensure coherence throughout Council of Europe member states with regard to compliance with preexisting legal obligations on accessibility. The Strasbourg Court can, therefore, play a role in ensuring that common standards are applied throughout Contracting States to the ECHR. Where the relevant domestic law has not been adhered to by national authorities and where this results in a violation of the ECHR, the Court may seek to hold the state accountable for its failure to implement domestic rights.

Secondly, the ECtHR could take a more proactive approach to assessing whether there is a role to be played by the private sector in circumventing - at least to some extent - resource limitations. ${ }^{109}$ While private actors are not bound directly by the ECHR, or international human rights standards generally, there is an emerging body of case law at the Strasbourg Court which establishes a variety of ways in which states can be held liable for the actions of non-state actors. ${ }^{110}$ Under the CRPD, States Parties are under an obligation to monitor accessibility in the private sector. Interestingly, the legislator in Botta and Zehnalová had passed relevant laws regulating standards pertaining to disability access regarding some activities in the private sector. That legislation was not implemented in the end. While the Botta line of cases came before the Court well before the adoption of the CRPD, this point will take on increased relevance as the CRPD is implemented in Council of Europe member states.

With regard to the role of the private sector, it was argued by the Czech government in Zehnalová that there were no budgetary implications for the state in respect of some

108. Özgür Gündem v Turkey App no 23144/93 (ECtHR, 16 March 2001) para 43.

109. See generally Andrew Clapham, Human Rights Obligations of Non-State Actors (OUP, Oxford 2006).

110. See Liam Thornton and Judy Walsh, 'The Convention in the Private Sphere', in Egan, Thornton and Walsh (n 23). 
of the alterations ${ }^{111}$ requested by the applicant, as the costs had been borne by the private owner of the facilities in question. However, no assessment was made by the Court as to whether the measures already provided to the applicant - in the form of an assistant and a payment towards the purchase of a special car - brought the negative impact of the inaccessibility for the applicant below the applicable threshold under Article $8 \mathrm{ECHR}$, nor was there any consideration of the private sector's potential role in relieving the burden on the state. Instead, the Court appeared to follow blindly the Czech government's submission that the measures already provided to the applicant should compensate for the fact that barrier-free access to all public buildings could not be provided immediately. In such instances, the Strasbourg Court could be more rigorous in its analysis of the rights of persons with disabilities, by considering whether the measures requested by the applicant fall under the Article 8 threshold, taking into account the measures already provided. The Court should also examine more stringently whether the justifications advanced by the state are plausible, taking into account whether the state has failed to ensure protection against interferences by private actors in the enjoyment of Article 8 guarantees.

\section{DISCRIMINATION AGAINST PERSONS WITH DISABILITIES: STEPS FORWARD IN THE ECtHR'S ARTICLE 14 JURISPRUDENCE?}

Having considered above the Court's approach to the interpretation of Articles 2, 3 and 8 ECHR and the potential influence of the CRPD in ensuring a harmonised approach to the social dimension of those rights, it is important to analyse the Court's burgeoning disability jurisprudence under the ECHR's non-discrimination norm. It will be argued that the trends identified under the non-discrimination norm might indicate a way forward for the types of 'social' claims arising under the substantive ECHR rights.

The prohibition of discrimination under the ECHR is contained in Article 14 and supplemented by Protocol 12. Article 14 ECHR lists a number of grounds on which discrimination is prohibited. This open-ended list has been interpreted by the Court to include disability. ${ }^{12}$ In recent judgments, the Strasbourg Court has moved in the direction of substantive equality, concerning itself 'with the effects of laws, policies and practices and with ensuring that they do not maintain, but rather alleviate, the inherent disadvantage that particular groups experience'. ${ }^{113}$ Outside of the field of disability, there seems to be a trend towards acknowledging the existence of positive obligations under Article $14 .{ }^{114}$ This trend can be seen most clearly in Thlimmenos $v$ Greece, ${ }^{115}$ Stec and others $v$ the

111. In that case, access was claimed in relation to some buildings in the private sector (eg cinemas, lawyers' offices, doctors' surgeries).

112. Glor v Switzerland App no 13444/04 (ECtHR, 30 April 2009).

113. UNCESCR, General Comment 16 on the equal right of men and women to the enjoyment of all economic, social and cultural rights (art 3 of the ICESCR), UN Doc E/C.12/2005/4 (2005) para 7.

114. For further commentary on this point, see Rory O'Connell, 'Cinderella Comes to the Ball: Art 14 and the Right to Non-Discrimination in the ECHR' (2009) 29(2) Legal Studies 211.

115. Thlimmenos $v$ Greece App no 34369/97 (ECtHR, 6 April 2000) para 44: 'The right not to be discriminated against in the enjoyment of the rights guaranteed under the Convention is also violated when States without an objective and reasonable justification fail to treat differently persons whose situations are significantly different'. 
United Kingdom, ${ }^{116}$ D.H. $v$ the Czech Republic ${ }^{117}$ and Horváth and Kiss v Hungary. ${ }^{118}$ The Court is also showing encouraging trends in its disability equality judgments postCRPD, with the prohibition of disability discrimination only having been confirmed explicitly by the Court after the UN Convention entered into force. The next subsection discusses the Court's post-CRPD case law, with a view to determining the influence of the CRPD, in conjunction with Article 14 ECHR, in promoting a coherent approach in the Strasbourg Court's disability case law related to prisoners with disabilities and the enjoyment of private life.

\subsection{Post-CRPD case law on Article 14 ECHR: strict scrutiny and positive obligations}

In Glor v Switzerland, the ECtHR found disability discrimination contrary to Article 14, in conjunction with Article 8 ECHR, by virtue of the fact that Switzerland had failed to carve out exemptions to a rule that imposed a penalty tax on persons deemed unfit to perform military service on grounds other than severe disability. The Court adopted a heightened standard of scrutiny, ruling that states have a 'considerably reduced' margin of appreciation in establishing different legal treatment for persons with disabilities. This was on account of the 'need to prevent discrimination against people with disabilities and foster their full participation and integration in society'. ${ }^{119}$ The adoption of a stricter standard of scrutiny stemmed from the Court's remarks that the CRPD represents a 'European and worldwide consensus on the need to protect people with disabilities from discriminatory treatment'. ${ }^{120}$

In narrowing the state's margin of appreciation, the Court enquired as to what prevented the authorities from 'setting in place special forms of service for people in a situation comparable to that of the applicant' and gave examples of what it considered to be viable alternatives for the applicant. ${ }^{121}$ This demonstrates, at the very least, "the Court's willingness to consider the potential special measures that States can take in order to accommodate the needs, and facilitate the rights, of disabled applicants'. ${ }^{122}$

In addition, the ECtHR has delivered a significant judgment on inequality related to the inclusion of students with disabilities in the field of non-compulsory education in Çam $v$ Turkey. ${ }^{123}$ The Court in that case unanimously held that there had been a violation of Article 14, in conjunction with Article 2 of Protocol No 1 ECHR (on the right to education), on account of the refusal to enrol the applicant as a student at the Turkish National Music Academy due to her visual impairment. Of particular note is the fact that the Court considered that the notion of discrimination on the ground of disability extends to the refusal to provide a reasonable accommodation to facilitate access by persons with disabilities to education. In that context, the Court referred to the importance of inclusive education and, in particular, the definition of reasonable accommodation

116. See Stec and others $v$ the United Kingdom App nos 65731/01 and 65900/01 (ECtHR, 12 April 2006) paras 51-64.

117. See D.H. and others v the Czech Republic App no 57325/00 (ECtHR, 13 November 2007) para 175 .

118. See Horváth and Kiss v Hungary App no 11146/11 (ECtHR, 29 January 2013) para 101.

119. Glor v Switzerland (n 112) para 84.

120. Ibid para 53.

121. Ibid para 94.

122. Broderick (n 30) 322-323.

123. Çam v Turkey App no 51500/08 (ECtHR, 23 February 2016). 
enshrined in Article 2 CRPD. It is noteworthy that the applicant had not even raised an argument claiming a denial of reasonable accommodation. ${ }^{124}$ The Court's decision in Çam certainly provides evidence of an integrated approach to human rights and increased links between the ECHR and the CRPD.

In Enver Sahin v Turkey, ${ }^{125}$ the applicant alleged, inter alia, a discriminatory interference with his right to education under Article 2 of Protocol No 1, in conjunction with Article 14 ECHR, due to the fact that he had been obliged to give up his studies following the refusal of his request for adaptation of the relevant facilities. The Strasbourg Court conceded that, in ensuring access for persons with disabilities to educational institutions, domestic authorities are in the best position to assess the margin of appreciation according to the funds available to them. ${ }^{126}$ Nonetheless, the Court affirmed that Article 14 ECHR must be read in light of the requirements contained in relevant instruments of international law - particularly, in light of the CRPD's reasonable accommodation duty. ${ }^{127}$ In finding a violation of Article 14, in conjunction with Article 2 of Protocol No 1 to the Convention, ${ }^{128}$ the Court found, inter alia, that the university had neglected to seek alternative solutions that would have enabled the applicant to resume his studies under conditions as close as possible to those provided to students without a disability, without imposing an undue or disproportionate burden. ${ }^{129}$ In several respects, the ECtHR's finding in Enver 'consolidates' the approach adopted by the Court in the Çam case above. ${ }^{130}$

In the equally promising case of Guberina $v$ Croatia, ${ }^{131}$ the Court held that there had been a violation of Article 14 ECHR, taken in conjunction with Article 1 of Protocol No 1 - protection of property - due to a complaint by the father of a child with a severe disability. The applicant alleged a failure of the tax authorities to take account of the needs of his child when determining his eligibility for a tax exemption on the purchase of property adapted to those needs. Notably, the Court applied a standard of strict scrutiny in the field of taxation, because the restriction concerned a particularly vulnerable group, namely people with disabilities.

The Guberina judgment is noteworthy for the particular emphasis placed by the Court on the key role that accessibility played in the life of the applicant's son, by facilitating his personal development and enabling him to participate fully in educational, cultural and social activities. In deciding the case, the ECtHR referred extensively to the CRPD, most notably to the provisions addressing, inter alia, reasonable accommodation, equality/non-discrimination and accessibility. The Strasbourg Court also referred to the CRPD Committee's General Comment No 2

124. See the views of Joseph Damamme, 'Disability Discrimination Because of Denial of "Reasonable Accommodations": A Very Positive Connection Between the ECHR and the UNCRPD in Çam v Turkey', <https://strasbourgobservers.com/category/cases/cam-v-turkey/> accessed 2 April 2018.

125. Enver v Sahin, App no 23065/12 (ECtHR, 30 January 2018).

126. Ibid para 64.

127. Ibid para 67.

128. Ibid para 75.

129. Ibid para 72.

130. Joseph Damamme, 'Disability and University (Pragmatic) Activism: The Pros and Cons of Enver Şahin v Turkey' (Strasbourg Observers, 9 March 2018) <https://strasbourgobservers.com/ 2018/03/09/disability-and-university-pragmatic-activism-the-pros-and-cons-of-enver-sahin-vturkey/>, accessed 3 September 2018.

131. Guberina v Croatia App no 23682/13 (ECtHR, 22 March 2016). 
(2014) on accessibility. ${ }^{132}$ Moreover, for the first time in its jurisprudence, the Court clarified that Article 14 covers discrimination by association - because of a relationship with a person with a disability - akin to the CRPD. This appears to be the Court's attempt to build another bridge between the UN Convention and the ECHR.

There may be a temptation to overemphasise the relevance of the Guberina case in the context of the Court's previous accessibility jurisprudence ${ }^{133}$ under Article 8 ECHR. As Waddington rightly points out, "no positive duties to render the environment more accessible were at stake' in Guberina, 'but rather the discriminatory application of an apparently neutral tax provision'. ${ }^{134}$ In spite of this, the Court's incorporation of the concept of 'reasonable accommodation' in its jurisprudence and its evolving understanding of that concept, particularly linking it with the non-discrimination norm, is a positive sign. Taking into account the principle of reasonable accommodation, the Court held that the domestic authorities' decisions, which failed to adapt the definitions used at the national level with regard to the particular needs of persons with disabilities, implied indirect discrimination - or discrimination by failure to treat differently people whose situations differed significantly. ${ }^{135}$

Having established the fact that the ECtHR is taking increased cognisance of positive obligations under the CRPD in its interpretation of Article 14 ECHR, it is important to consider the role that this could play in promoting a more coherent approach in the Court's case law related to prisoners with disabilities and the enjoyment by persons with disabilities of their right to private life.

\subsection{Article 14 ECHR and the CRPD: promoting a coherent approach in the Court's disability case law relating to detention and private life}

Article 14 is evolving in a manner which may signal that the Court is willing to address systemic inequality and disadvantage in the distribution of social provisions to vulnerable groups and individuals. It is well known that Article 14 can only be relied upon when another ECHR provision is applicable. Nonetheless, Oddný Mjöll Arnardóttir has identified three distinct kinds of magnifying effects that Article 14 can have in relation to other ECHR rights. ${ }^{136}$ Two of those are of particular importance in the present context.

According to Arnardóttir, the first magnifying effect occurs when another ECHR article is in fact applicable, but the discriminatory element functions as an additional violation or as an aggravating factor. With regard to the Court's case law on Articles 2 and 3 ECHR, it is predicted that an increased focus on the non-discrimination norm, particularly under the influence of the CRPD, will serve to highlight the discriminatory effect of the substantive disadvantage to which prisoners with disabilities are subjected. This, in turn, should serve to influence an increase in positive measures to be accorded to such prisoners. It might also encourage the Court to outline the nature and scope of states' positive obligations in detention settings and to take a more coherent approach to

132. UN Committee on the Rights of Persons with Disabilities, General Comment No 2, 11 April 2014, UN Doc CRPD/C/GC/2.

133. See Botta v Italy (n 84); Zehnalová and Zehnal v the Czech Republic and others (n 84).

134. Lisa Waddington (n 47) para 14.

135. Guberina v Croatia (n 131) para 57.

136. Oddný Mjöll Arnardóttir, 'Discrimination as a Magnifying Lens: Scope and Ambit Under Article 14 and Protocol No. 12' in Brems and Gerards (n 95). 
determining the applicable threshold, in particular whether support already provided by a state to an applicant with a disability needs to be reassessed.

The second kind of magnifying effect outlined by Arnardóttir concerns a situation where the issue in question does not come within the legal scope of a Convention article but where the ambit doctrine leads to acknowledgement under the Convention, from the perspective of non-discrimination, of an additional interest related to that right. With regard to Article 8 ECHR, Sandra Fredman has argued that '[i]t is when allied with the equality guarantee in article 14 that article 8 has constituted the most potent source of positive duties'. ${ }^{137}$ The ECtHR has not yet exhausted its potential in defining the limits of the concepts of private life, directness and immediacy in the context of Article 8. In the cases of Botta and Zehnalovà, outlined above in Section 5, the applicants tried to rely on Article 14 in conjunction with Article 8. However, since the Court found, in both instances, that there had been no interference in the applicants' private lives - and, thus, that Article 8 was not applicable - their claims were unsuccessful. This precluded the invocation of Article 14 ECHR. Increased focus by the Strasbourg Court on Article 14 as well as the Court's enunciation of positive obligations under that article bode well for the further development of positive obligations under both the ECHR's non-discrimination provision and also across the substantive articles of the ECHR. The Guberina judgment, in particular, signals the fact that the Court's understanding of disability-based discrimination is expanding. However, as Waddington points out, 'one cannot conclude that the Court is now on the brink of regarding an inaccessible environment as a breach of article 8, although it may have edged a little closer to reaching that conclusion at some point in the future'. 138

At the very least, given the trends highlighted above with regard to the Court's Article 14 case law, it is likely that the Court will continue to consider whether a state is in compliance with its positive duties under the CRPD in assessing whether the alleged discriminatory act of a state can be objectively justified. This could potentially lead to a more coherent approach by the ECtHR and a renewed focus on the nondiscrimination norm in disability cases, including the granting of positive measures in the form of reasonable accommodation. In turn, this could lead the Court to highlighting breaches, and consequent positive obligations, in cases related to other substantive ECHR rights. Nevertheless, this assertion must be tempered by the margin of appreciation doctrine, which is likely to restrain the Court from imposing far-reaching positive obligations (such as accessibility obligations) under the substantive ECHR rights.

\section{CONCLUSION}

Gerard Quinn and Theresia Degener claim that 'disability challenges society to live up to its values and sets human rights law the task of engineering positive change'. ${ }^{139}$ The ECtHR can potentially fufill this task by taking a more coherent and principled approach to disability rights in cases that come before it, guided by the CRPD's underlying values. As highlighted in the introduction to this article, such a principled

137. Fredman (n 1) 207.

138. Lisa Waddington, 'Europees Hof voor de Rechten van de Mens, Guberina tegen Kroatie', No 23682/13 (22 March 2016) 17(3) European Human Rights Cases 284, 288.

139. Gerard Quinn and Theresia Degener, Human Rights and Disability: The Current Use and Future Potential of the United Nations Human Rights Instruments in the Context of Disability (United Nations, New York and Geneva 2002) 13. 
approach would involve a more cautious scrutiny by the Strasbourg Court of state action, in order to ensure coherence throughout Council of Europe member states, in particular with regard to states' compliance with preexisting legal obligations. It would also entail an increased role for the Court in guiding the normative framework of rights, inspired by the principles embodied in the ECHR itself, and in ensuring that common standards are applied throughout Contracting States. Additionally, a more principled approach would serve to increase accountability in circumstances where states are responsible for disability-related socio-economic disadvantage under the applicable threshold of a particular ECHR right.

The Strasbourg Court has traditionally emphasised the negative nature of Convention rights in terms of non-interference. In more recent times, the Court has developed some principles that are laden with inherent socio-economic implications with respect to certain ECHR rights. Protection for socio-economic rights under the ECHR remains limited, but the impact of some recent judgments of the Strasbourg Court in relation to positive obligations concerning - in particular - the right to life, the prohibition on torture and the nondiscrimination norm are significant. While the Court has been reluctant to read substantive socio-economic principles into ECHR provisions, particularly with regard to the right to private and family life, there seems to be an emerging judicial consensus in the Strasbourg Court for protecting those who are exceptionally vulnerable. ${ }^{140}$

The ECtHR has not always been consistent in its disability case law, and neither has it been consistent in invoking the CRPD. Having said that, the Court is showing an increased willingness to emphasise states' positive obligations under the CRPD when determining a breach of the ECHR. A move towards substantive equality is evident in the Strasbourg Court's jurisprudence, particularly with regard to positive obligations in the form of reasonable accommodation duties. While there are clear differences between the ECHR and the CRPD in terms of their scope of application, there are, nonetheless, normative synergies between the two treaties. Moreover, the Strasbourg Court appears to be building some bridges between Council of Europe jurisprudence and the CRPD.

This paper argues that the Strasbourg Court should develop a more principled approach to the interpretation of ECHR rights, including a clearer duty to reasonably accommodate persons with disabilities under the ECHR, since the failure to incorporate reasonable accommodation duties into ECHR jurisprudence results in clear instances of discrimination. With regard to more widespread and resource-intensive positive duties, the limits of state responsibility remain uncertain under the ECHR. What is particularly worrying in some disability rights' claims is the Court's fragmented approach to the development of positive obligations and its inconsistent invocation of the margin of appreciation. In its jurisprudence, the Court has largely failed - both within and outside the disability field - to truly recognise the interface between civil and political and socioeconomic rights and to define its role in ensuring that the rights embodied in the ECHR are applied equally to persons with disabilities.

At present, there is little evidence to suggest a bold move by the Court towards the imposition of resource-intensive duties on Contracting States. This is understandable in light of the margin of appreciation doctrine. Nonetheless, a more principled model of adjudication for the protection of disability rights in the socio-economic

140. See the comments of the ECtHR in M.S.S. v Belgium and Greece App no 30696/09 (ECtHR, 21 January 2011) para 251; see also D.H. and others $v$ the Czech Republic (GC) App no 57325/00 (ECtHR, 13 November 2007) para 182; Kiyutin v Russia App no 2700/10 (ECtHR, 10 March 2011) para 63. 
sphere would be a welcome step forward. The suggestions put forward in this paper ${ }^{141}$ concerning the potential sphere of influence of the CRPD could serve to guide a more coherent approach to the interpretation of ECHR rights. While the role of the Strasbourg Court is not to encroach on Contracting States' autonomy with regard to resource allocation matters, the Court could certainly play an increased supervisory role in the manners detailed throughout this paper, in order to enhance the protection of disability rights in the Council of Europe.

Future case law may require the Court to look beyond its jurisprudence to date, to give a comprehensive interpretation of the ECHR - one which goes to the heart of the issues in question and which touches upon the substantive disadvantage experienced by persons with disabilities in their everyday lives. On account of the high number of Council of Europe member states that have ratified the CRPD and are implementing it at the national level, the Strasbourg Court's role in promoting common values and standards of respect for human dignity in member states is paramount. It remains to be seen if, and how, the Court will expand upon its current socio-economic rights jurisprudence in light of domestic obligations arising from the CRPD and delicate resource implications for states. Whatever approach it takes, the Strasbourg Court should bear in mind the words of Anna Lawson: that the claims of individuals with a disability to a place in mainstream society 'is a matter of equality and human rights, with which the ECtHR should be concerned'. ${ }^{142}$

141. See, in particular, Sections $4.3,5.2$ and 6.2 above.

142. Anna Lawson, 'The UN Convention on the Rights of Persons with Disabilities and European Disability Law: A Catalyst for Cohesion?' in Arnardóttir and Quinn (n 27 ) 92. 